\title{
Contracting in land and natural resources: a tale of exclusion
}

\author{
Federica Violi* \\ Assistant professor in International Law, Erasmus University Rotterdam, The Netherlands \\ ${ }^{\star}$ Corresponding author. E-mail: violi@law.eur.nl \\ 'a little patch of ground/ \\ That hath in it no profit but the name.' (Hamlet, 4.4.18-19)
}

\section{Introduction}

By browsing the website of Land Matrix, ${ }^{1}$ one can measure the extent of land-related large-scale investments in natural resources (LRINRs) ${ }^{2}$ and place it on the world map. At the time of writing, the extent of these investments covers an area equal to the surfaces of Spain and Portugal together - or, for football fans, around 60 million football pitches. These investment operations have often been saluted as instrumental to achieve the developmental needs of host countries and as the necessary private counterpart to state (and interstate) efforts aimed at (sustainable) development goals. Yet, the realities on the ground offer a scenario characterised by severe instances of displacement of indigenous or local communities and environmental disruptions. The starting point of this short essay is that these 'externalities' are generated through the legal construct enabling the implementation of these investment operations. As such, this contribution lies neatly in the line of research set forth in the excellent books of Kinnari Bhatt and Jennifer Lander, from the perspective of both the development culture shaping these investment operations and the private-public environment in which these are situated. The essay tries and dialogues with both components, while focusing at a metalevel on the theoretical shifts potentially geared to turn a 'tale of exclusion' into a 'tale of inclusion'.

The paper covers a fraction of a broader research project that I am currently conducting on the triangulation of state (investment) contracts. Therefore, section 2 offers an overview of the background and premises of this research, and shows the relevance of the focus of this essay, namely the (mis)use of the 'private'-law notions of property (section 3.1) and contract (section 3.2), and private-international-law techniques (section 4) employed in land-related large-scale investments in natural resources. Section 5 concludes. The aim is to show both how these notions have been interpreted and applied in the context of LRINRs to advance private interests and how these could be reshifted to accommodate competing interests typically excluded or sidelined by the applicable regulatory framework.

\section{Background and premise}

LRINRs are embedded within a multilevel and overlapping system of rules (Violi, 2017). Investment operations are usually covered by (1) Bilateral Investment Treaties (BITs) between host state and home state; and (2) state contracts concluded between the host state and private investors. The latter formally bilateral private - agreements typically include the obligations that the host state and the

\footnotetext{
${ }^{1}$ See https:/landmatrix.org/map/ (accessed 2 October 2020).

${ }^{2}$ For the purposes of this research, this phrase refers to contractual arrangements for exploration and exploitation operations that require access to and use of land.

(c) The Author(s), 2021. Published by Cambridge University Press. This is an Open Access article, distributed under the terms of the Creative Commons Attribution-NonCommercial-NoDerivatives licence (http://creativecommons.org/licenses/by-nc-nd/4.0/), which permits noncommercial re-use, distribution, and reproduction in any medium, provided the original work is unaltered and is properly cited. The written permission of Cambridge University Press must be obtained for commercial re-use or in order to create a derivative work.
} 
investor reciprocally commit to in relation to the investment activity. Such contractual terms seemingly bind only the host state and the investor as the parties to the agreement. In reality, these transactions have far-reaching effects exceeding this bilateral relationship, as aptly illustrated by the following example. In 2009, the Republic of Cameroon and SG Sustainable Oils Cameroon PLC (a US-based company) concluded a state contract for the agricultural use of the land for palm-oil plantations. The investor was granted a 99-year (renewable) lease of over 80,506 hectares of land. In the event of a conflict between the contract and any law, the former shall prevail. Amongst others, the investor is (1) granted the authority to maintain law, order and security over the land in question, including the power to search, apprehend, detain and evict unauthorised persons; and (2) exempted from any change in the law that might adversely interfere with the implementation of the investor's activities, all combined with a direct reference to the overarching BIT between the US and Cameroon and a dispute-settlement clause locking in recourse to international arbitration. Clearly, state contracts are crucial in framing the investment activity and determining the effects of the operation. From an analysis of the contractual terms, it emerges that contracts of this nature generate a series of interrelated consequences: they (1) enable a significant transfer of control over extensive areas of the host state's territory to private entities; (2) remove the investment operation from the territorial authority of host countries; (3) and result in the creation of a legal enclave. Typically, such an enclave is entangled in a multiplication and overlap of different spatial, temporal and normative levels that are deprived of the host state's regulatory powers and left to the discretion of the investors (Violi, 2016; Arcuri and Violi, 2017). As recently articulated by Cotula (2020), these enclaves disintegrate the local social and legal regimes to favour the integration of commodified natural resources at a transnational level in global supply chains. These spaces exist and operate transnationally, yet they are completely disarticulated nationally (Violi, 2016), to the point of creating a 'structural hole in the tissue of sovereign territory' (Sassen, 2013, p. 28). As a result, other 'stakeholders' - formally third parties to the contract - may be affected by these operations and not be able to rely on their own state to adequately protect their interests. The complex international legal framework that these contracts are embedded in allows a 'super' protection of the investor's foreign property and contractual rights (Violi, 2016; Cotula, 2016; Arato, 2015). Strikingly, the rights and interests of the local population are much less forcefully protected. Thus, the affected population might bear the costs without participating in the benefits.

One cannot but observe that such a construct is designed to artificially exclude the host state's population from the relevant governance framework. And it is an observation that Bhatt and Lander share in their excellent work: it is the regulatory 'vicious circle' that these operations are entrenched in that enables this systematic exclusion. In this 'vicious' multilevel system of norms, contractual terms and their (blurry) interaction with overarching international investment agreements (IIAs) play an enormous yet not always fully appreciated role. The work of Bhatt and Lander brings this forward and exposes a system that, in the words of Bhatt, is composed of a 'hyperplurality of norms' (Bhatt, 2020, p. 19), expediently designed to lock in investors' preference and power.

Resting on the same premise, the general key aim of my broader research is to address this ill-fitting bilateral configuration, by internalising the position of affected stakeholders into the relevant legal framework and identifying external and internal parameters (Cotula, 2018) of validity and legitimacy for contracting in natural resources. The main idea is to advance a triangular (host states-investoraffected population) reconceptualisation of state contracts ${ }^{3}$ that incorporates the position of affected stakeholders (formally third-party interests) into a new theoretical design. This triangular analytical lens enables questions relating to contractual governance and restrictions over party autonomy, as well as structural changes in how public authority over resource allocation is shaped and exercised, to be reframed. Accordingly, the idea of triangulation internalises ex ante the multi-stakeholder relevance of investment operations into the legal framework regulating LRINRs. The question is, of course, how.

\footnotetext{
${ }^{3}$ For the purposes of this contribution, the terms 'state contracts' or 'investment contracts' are used interchangeably to refer to an investor-state contractual relationship regulating a given investment operation.
} 
Critically, both Bhatt and Lander take on a methodological approach that allows them to enclose the entirety of this legal framework. Their work is not limited at looking, for example, at how contracts and private law order relevant legal relations, or how (public) international investment law assesses host states' conduct. Instead, they look at the interaction of various levels and forms of law and regulation, without losing sight of the complexity. Their work shows that it is precisely within this interaction that fundamental ruptures of the rule-of-law principles are to be found. And structural efforts to address these ruptures cannot but operate at this transnational and interactional level. For the same reason, I endorse an integrated approach combining notions of both public international law (PIL) and private law (including conflict of laws $(\mathrm{CoL})$ ), and seek to explain how these impart normative meaning to each other, while also relying on existing socio-economic theories of the (re)distribution of wealth. The broader research that I am conducting looks at these three interconnected fields - PIL, private law and $\mathrm{CoL}$ - and relies specifically on (1) internal economic self-determination as a means to convey a pluralistic understanding of the public interest into the realm of governmental economic decision-making; (2) the relationship between IIAs and contracts; and (3) the distributional effects of private-law rules on contract and property. What I intend to revert is the assumed bilateral theoretical underpinning of state-investment contracts, which has so far steered both judicial and academic approaches, and imposed a focus on effects rather than on structural causes. This short essay is limited to the private-law dimension of my research. Yet - as these three areas are interconnected - cursory reference will be made to how PIL, private law and CoL interact and shape each other. ${ }^{4}$ The aim of the next two sections is to show how the notions of contract and property are employed in the context of LRINRs, and how these could be retheorised to accommodate the idea of triangulation and, more generally, meaningful inclusion.

\section{Private-law tools and paradigms in LRINRs}

When exercising their contractual capacity, the current structure of state contracts allows countries to disregard rights and interests of the local population, while the current international and contractual system protects private investors. At a deeper level, while it is true that state contracts formally constitute a private tool, host states play a double role, both as the contracting party and as sovereigns acting in the public interest (Sornarajah, 2010). Such a feature creates the following situation: on the one hand, via state contracts, sovereign prerogatives are subject to a private agreement; on the other hand, investors might, under certain conditions, recur to the protection granted by PIL at the treaty or customary-law level for the violation of contractual rights. Hence, while states' interests into development find their way through a (formally) private tool, contractual clauses might 'internationalise' investors' private interests and allow companies to claim their (extensive) rights before an arbitral tribunal. Substance wise, this is coupled with contractual clauses that - as mentioned already in section 2 - crystallise a voluntary relinquishment of powers on the part of host states and grant a sort of 'law-making' power - combined with stark discretion - to corporations (Arato, 2015; Violi, 2020) on vast areas of host countries' territory.

Part of the problem relates to how the notions of 'property' and 'contract' are conceptualised in LRINRs and large investment operations more in general. The point to start from - too often overlooked - is that rules on contract enforcement and property protection have significant distributional effects. The underlying theoretical justification of contract and property employed in LRINRs will therefore have a crucial role in how these operations play out in practice. As Lander lucidly articulates in her book, the 'transnational' protection of capital is of utmost relevance for how 'development' is conceived of and has heavily shaped states' decision-making from within (Lander, 2020, p. 18), perfectly in line with the role that the Washington Consensus assigns to host states. The notorious 2011

\footnotetext{
${ }^{4}$ To offer just a couple of examples, the project looks into what endorsing a certain understanding of self-determination would imply for a reconceptualisation of contracts or how a certain understanding of property would change the interpretation of investors' substantive standards of protection under BITs.
} 
World Bank report (Deininger et al., 2011), for example, calculated the amount of available ('waste') land in developing countries based on notions of 'productiveness' and 'efficient use of resources' that would ignore traditional and customary uses of land, based on what a commodity/global value chain-oriented mindset would perceive as being so. Yet, this construction is presented as 'necessary' for the purposes of development. And the implementing 'tools' par excellence employed in the development discourse are, indeed, property and contracts.

It is worth noting at this point that many rule-of-law conceptualisations are fully integrated in this sort of discourse. Property and contract are typically considered as an object of protection - quite statically, I dare add - and, as such, reflective of individual freedoms to be shielded from undue discretion and interference of state's power. Yet, this idea perpetuates a very limited understanding of the rule of law, merely equated with the presence of 'strong' legal and judicial state institutions serving (a specific interpretation of) property and contract protection (Krygier, 2016). This approach obscures two fundamental aspects that are both present in the work of Bhatt and Lander. First, property and contracts are in fact active sites of power, rather than passive sites of vulnerability to states' whims. Second, we can observe a reconfiguration of the role of the state as facilitator of (extensive) private power. The example of state (investment) contracts is particularly fitting. The relational and substantive characteristics of these contracts, briefly delineated above, grant investors the power to 'make' the law, 'dictating legal norms that overrule domestic law and rewrite public choice and [can] demand compliance thereof through a strong system of enforcement' (Violi, 2020, p. 91). This includes directly enforcing contractual rights on 'third parties'. As said, property rights attached to or derived from contractual arrangements add a stark level of exclusive effective control over the investment area - a perfect recipe for the exercise of structural and institutional power on the part of investors in a legal enclave in which host states' domestic law barely applies. Yet, the legal framework is such that this power is not met with an adequate system of accountability, predictability or avenues for participation (in the broader sense) the three forms identified by Krygier in his work to define the 'arbitrariness' of power (Krygier, 2016). The reflections that follow show both how much the current legal framework is influenced by a certain political and theoretical understanding of property and contracts, and how this can be shifted to curb the exercise of arbitrary private power in the three forms identified by Krygier.

\subsection{The 'terrible'5 right to property}

It is widely acknowledged that property protection is one of the key issues in economic governance and that in fact it represents one of the techniques of wealth and resource allocation and management. A lot more complex is to discern and determine what set of interests and values property protection implements and articulates (Perrone, 2016). The way in which property is conceived of in investment operations is mostly in its modern - liberal - interpretation: as a right characterised by absolute and exclusive enjoyment. Law and economics scholars even identify the 'exclusiveness' of property as one of the fundamental criteria for an efficient allocation and management of resources. And this is clearly visible in both the way in which property reforms have been designed for developing countries to access international financial institutions funds and the way in which international investment law has evolved around the protection of investors' property rights, whereby absoluteness and exclusiveness are the key features. Such a conceptualisation seemingly 'does not address the question of how people become [sic] to own resources and how initial distribution arises in the first place' (Panesar, 2000, p. 135).

Yet the paradigm of current times, or at least the 'universal aspiration' (Perrone, 2016) - especially in a context permeated by structural inequality in the allocation and distribution of resources - is rather one of democracy, participation and inclusiveness. Such an aspiration is typically connected with political participation. However, participation has crossed over into the realm of socio-economic decision-making and structures. This means both participating in sites where decisions are taken and

${ }^{5}$ This phrase is employed by Rodotà (1990) in his book. 
accessing processes of resource distribution. This is reflected in - and to a certain extent an operationalisation of - economic self-determination, as an obligation of states to take decisions advancing the interests and well-being of their population: a 'well-being' that is not abstractively deduced, but is rather based on concrete participatory processes.

Pouring this reasoning into private law, in his Il nuovo volto della proprieta ${ }^{6}$ (1985), Scalisi further articulated the idea - engrained in postwar social constitutional theories - that property performs a social function in the context of a participatory model of economic decision-making and access to (and enjoyment of) resources. This understanding of property tries and breaks the rigidity typically associated with it and gives space to a legal construction of property as a 'variable geometry' right. The variability suggests a non-unitary model of the property statute in which rights-holders entertaining a formal ownership relationship with an object share accessibility and enjoyment with other subjects that hold different yet equally relevant types of (collective or individual) entitlements and rights. The idea, therefore, is to disentangle the right to property from an individualistic and exclusive power of enjoyment and clear the path for a plurality of 'property' schemes. In such schemes, enjoyment is shared at different levels (and moments) by different subjects holding different, yet equally relevant, entitlements over the same object. This means that the proprietary situation of a single subject cannot but be relational and has to be appreciated, qualified and limited (if not, in certain cases, compressed) in light of other potentially relevant entitlements. Applied to the context of investment operations, this might, for example, reinforce the position of rights to use of local communities over a certain portion of land, without these being simply displaced by investors' property rights. The latter would then be limited, both in terms of exclusive enjoyment and in terms of benefit and expectations of wealth maximisation. Further, such a conceptualisation of property gives even more flesh to Free Prior and Informed Consent (FPIC) or consultation processes, involving those potentially affected already in making the decision on the allocation of a certain resource, rather than being confronted by a decision already taken that they can (in the best-case scenario) only object - and often only formally so - as Bhatt shows in her central chapters (Bhatt, 2020, p. 183). An idea of plurality and participatory property schemes does not only reflect a more comprehensive understanding of the political economy of resource allocation, but would also reflect international and national case-law tendencies protecting a variety of different rights and entitlements under the right-to-property rubric. ${ }^{7}$ In other words, a theoretical shift accommodating the triangulation of contracts (host states, investors, affected population) in the context of LRINRs would require property schemes to be both objectively and subjectively connoted, depending both on the quality of the 'good' and the interests attached to the entitlement- or rights-holders.

\subsection{The contractual imperative of party autonomy}

Contracts are equally imbued with this idea of development inspired by a strong protection and stability of investors' rights as the obvious route to an efficient management of resources. What emerges strongly from the regime of contracts applied in the context of LRINRs is the presence of two main characteristics: first the 'propertisation' of contracts in investment arbitration and, second, contracts as the ultimate incarnation of party autonomy. Very briefly, regarding the first characteristic: inspired once again by the notion of exclusiveness, arbitral case-law shows a stark tendency to extend expropriation-related norms and standards to contractual violations that amounts to a 'deprivation' or 'nullification' of the investment, albeit not amounting to an actual deprivation of property. This has inevitably expanded the protection of foreign investors and their shield against state intervention,

\footnotetext{
${ }^{6}$ 'The new face of property' (translated by the author).

${ }^{7}$ On the extension of the ECHR property-protection rights to land different from formal ownership, see ECtHR, Holy Monasteries v. Greece, Judgment of 9 December 1994. Similarly, in the African regional context on domestic customary tenure rights, Tanzanian Appeal Court, in Attorney General v. Aknonaay and Another (Civ App. 31 of 1994) [1994] T.Z.C.A. 1 (21 December 1994). On the protection of collective rights to land, see IACtHR, Moiwana Community v. Suriname, Preliminary Objections, Merits, Reparation sand Costs, Judgment of 15 June 2005; and IACtHR, Saramaka People v. Suriname, Judgment of 28 November 2007.
} 
with significantly concrete consequences, such as the calculation of damages. The second aspect is even more interesting, as it goes to the core of the following: what are the (external and internal) parameters of the validity of contracts in natural resources? (Cotula, 2018). The question is certainly complicated by the context of these investment operations. Yet, it is an important question to ask if one considers that, also for investment contracts, party autonomy seems to be the paramount paradigm, both in contract-drafting and in contract enforcement. Still, party autonomy is not a value per se. It needs to be instrumental for the achievement of substantive interests that are relevant within the pertinent legal (eco)system. As mentioned above, ideally, investment contracts with a host state should convey the pursuit of public interest and the advancement of the well-being of the host state's population. Contractual reality seems instead rather deaf to the pursuit of a public interest that goes beyond a hollow formulation of values. There is little to no indication that a host state's decision to be bound by a certain contract was inspired by a pluralistic and participatory process of public-interest formation. Not only that, prevalence clauses in contractual arrangements ${ }^{8}$ might even have the effect of altering the hierarchy of domestic legal sources, placing the contract above ordinary laws and securing private interests at the level of constitutional norms, offering a perfect example of what Lander defines as 'a de facto reconstitution of the scope of democratic politic' (Lander, 2020, p. 224).

Yet, when it comes to the regulatory framework of resource allocation and (re)distribution of wealth, party autonomy cannot be considered valid when it is pushed to the point of sidelining the interests (and rights) of the local population, relegating them to the formal role of 'third-party' interests, all while private investors' interests take on a constitutional quality. This is strikingly at odds not only with an aspiration of democracy and participation, but also with the notion of economic selfdetermination as articulated above. Ideally, considering the significance of LRINRs in political economy, investment contracts should move away from a mere expression (and maximum protection) of private interests and be rather conceived of as an organisational model for resource allocation, where a plurality of interests converge. Such an idea might be detected in the recent contractual practice of community-investors or even (albeit very limited) tripartite contracts (Gathii and OdumosuAyanu, 2016; Odumosu-Ayanu, 2014). Yet, even multiparty contractual arrangements might still not provide a sustained answer, if not engrained in a theoretical shift. These transactions are based on the paradigm of consent, or at best on separate benefit-sharing arrangements, meaning that no input is given on the part of local communities to the desirability and design of the investment operation ex ante. Furthermore, several studies (Cotula, 2018; Szoke-Burke and Cordes, 2017) have already shown how representation of local communities in this context is highly problematic and asymmetric power relations are not captured by the rather formal feature of consent. Such constructs might simply be transformed into yet another risk-management tool for the investor.

This means that a change in the analytical framework for contract regulation cannot stop at merely including local communities as parties into the contract. It requires looking transversally at the entire relevant and multilayered LRINRs governance, and making sure that contracts are included in a framework in which self-determination inspires definitions of 'community' and 'collective'; investors' property rights and expectations are (re)qualified; meaningful participation in domestic decisionmaking is guaranteed ex ante rather than ex post, in a conflict or impact phase. It also means, as articulated in the next section, including domestic-land tenure and customary rules in the relevant

\footnotetext{
${ }^{8}$ Take e.g. s. 22.1 of the Convention between the Republic of Cameroon and SG Sustainable Oils Cameroon PLC mentioned in section 2 of this essay: 'Applicability of Cameroonian Law.... Investor shall be subject to Law as in effect from time to time, including respect for labor, environmental, health and safety, ... and shall conduct itself in a manner consistent with Cameroon's obligations under international treaties and agreements, insofar as those have the effect of the Law. Sections 22.2. ... However, in the event of a conflict between this Convention and any Law, except for the Constitution of Cameroon, in effect as of the date hereof, the rights, obligations and duties of a Party shall be deemed to be those set forth in this Convention .... Additionally, Art. 45 of the Constitution of the country foresees that duly ratified international agreements have a hierarchical effect that is superior to ordinary laws, without, however, acquiring a constitutional value. It follows that if any contractual clause is in conflict with international treaties ratified by Cameroon, the latter would probably succumb.'
} 
framework, as these typically articulate a multidimensional understanding of land, beyond its bare commercial or commodity value.

\section{Private international law: a mixed blessing?}

As mentioned above, relevant private norms consolidate the principle of party autonomy, leaving contractual regulation entirely to the parties. CoL, more specifically, remains on the side of the investment/public-goods discourse. In her inspiring piece, Private International Law Beyond the Schism, Horatia Muir Watt (2011) shows how private international law has willingly chosen not to look at public goods or public values. While hidden behind aspirations of axiological neutrality and 'process-based technicality', this wilful blinding decision has paved the way for the 'privatisation' of sovereignty on the part of private actors operating in the transnational realm and shaping global authority and interests. According to her, CoL still remains reluctant to offer any changes to the relationship between law and authority, neglecting the fundamental social and distributive function of private ordering.

The way in which this 'non-interest' of CoL in reigning in private power plays out is immediately visible in the context of contracting in natural resources. Bhatt shows, for example, how debt instruments that are part and parcel of the regulatory context of certain development projects systematically refer to English law as the applicable law. While standardised practice, the renvoi to English law is striking for the remoteness of this 'choice' from the actual local environment of the project itself. Owing to the 'sanctity' that party autonomy enjoys under CoL, Bhatt explains how the selection of such a law is in fact due to the high degree of contractual liberty it affords (Bhatt, 2020, p. 50). Yet, how is such a choice going to impact the project environment when it comes to the rights and interests of those potentially affected? Once again, this technique sanctions the ability of investors to pick, choose and enforce whatever legal order (or aspects of it) is more convenient, all the while almost completely sidelining the interests of those affected.

When it comes to investment contracts per se, the choice of law clauses can also be problematic, for two reasons: first, albeit less frequently, parties might select a foreign legal system as the applicable law to the contract ${ }^{9}$; second, even when referring to domestic law, such clauses are typically limited to 'state-made' law and subject to stabilisation clauses. While there is no space to analyse the latter, the reference to state-made law is very interesting, as it excludes from its scope the application of domestic customary rules protecting communities and their values.

CoL has insisted on its axiological neutrality. Yet, Muir Watt has convincingly shown how it does in fact possess the methods and the techniques to articulate a 'political project for the global governance of private power' (Muir Watt, 2011, p. 355). More specifically - along the lines suggested by Muir Watt - in the context of LRINRs, the idea could be to reinterpret functional proximity as 'affectedness' and employ it as a default paradigm for applicable law clauses (even in the absence of an express choice of the parties). 'Affectedness' as a connecting factor conveys the idea that domestic customary rules might very well apply to the contract, as these norms give voice to those impaired by a certain investment operation. The notion of affectedness would also provide a means to re-embed local values in the regulatory framework of the investment operation. Similarly, applicable law could be extended to include non-positive law. This happens already with lex mercatoria and there is no valid reason why this should also not happen with, for example, the Voluntary Guidelines on the Responsible Governance of Tenure of Land, Fisheries and Forests (VGGT) or other relevant soft-law instruments of resource governance. Regardless of what one thinks of these standards and their (limited?) effects, this could well represent an entry point for interests in the contractual framework that are not merely private and stabilised. Finally, albeit admittedly dependent upon the competent court (or tribunal), the idea of transnational and/or

\footnotetext{
${ }^{9}$ See e.g. Contrat d'Exclusivite pour I'Utilisation de Terre entre Agro Africa (Norvège) et Kounkane, Sénégal, a community-investor agreement that indicates at Art. 5 French law as the law applicable to the contract.
} 
domestic public policy might be reinterpreted to include resource-distributive considerations as limitations to the full operationalisation of parties' choice of law.

\section{Conclusions}

This brief essay has shown how certain legal notions that are presented as static and rigid are in fact shaped by a specific understanding of economic governance. It has also tried to show how these can be reinterpreted to accommodate different models of resource allocation and governance, more in line with aspirations that are (seemingly, at least) shared at a universal level. The theoretical shifts proposed herein do nothing but take the following into consideration: the idea of 'private' used to indicate a convergence between an area of law (private law) and a certain set of interests (issues not involving the public dimension), and 'was to be taken as a clear indicator of the absence of any power issue' (Muir Watt, 2011, p. 392). Now, 'private' means at best 'non-state'-made or -originated. The insistence of scholars, practitioners and legislators to keep employing the understandings of private-law notions that fitted (at best) in the past is certainly misplaced nowadays, where private power does undoubtedly involve and shape public order and cultures, and clearly contributes to rule-of-law ruptures. The books of Bhatt and Lander offer a crystal look into this reality. It is now the moment to widely embrace it and 'bend' legal and normative interaction in the transnational legal realm, in ways that articulate inclusion and distributional justice. In doing so, one should be reminded of the following words:

'Rising to the challenge transcends conventional disciplinary boundaries - between national and international lawyers, between experts specialised in different field of international law, and between lawyers and political economists. It calls for transdisciplinary action-research methods that can interrogate the interplay of national and international law in sensitive socio-political terrains.' (Cotula, 2019)

\section{Conflicts of Interest. None}

Acknowledgements. The author would like to thank Prof. Dr Sanne Taekema, Dr Kinnari Bhatt and Dr Jennifer Lander for the fruitful and inspiring exchange around this Book Symposium, as well as for their comments on a earlier version of this paper. The usual disclaimer applies.

\section{References}

Arato J (2015) Corporations as lawmakers. Harvard Journal of International Law 56, 229-295.

Arcuri A and Violi F (2017) Reconfiguring territoriality in international economic law. Netherlands Yearbook of International Law 2016, 175-215.

Bhatt K (2020) Concessionaires, Financiers and Communities: Implementing Indigenous Peoples' Rights to Land in Transnational Development Projects. Cambridge: Cambridge University Press.

Cotula L (2016) 'Land grabbing' and international investment law: toward a global reconfiguration of property? In Bjorklund AK (ed.), Yearbook on International Investment Law \& Policy 2014-2015. Oxford: Oxford University Press, pp. $177-214$.

Cotula L (2018) Reconsidering sovereignty, ownership and consent in natural resource contracts: from concepts to practice. In Bungenberg M et al. (eds), European Yearbook of International Economic Law 2018. Cham: Springer, pp. $143-174$.

Cotula L (2019) Law and Political Economy of Commodity Rushes: Reflections on 'Land Grabbing' in the Global South. Law and Political Economy Blog.

Cotula L (2020) (Dis)integration in global resource governance: extractivism, human rights, and investment treaties. Journal of International Economic Law 23, 431-454.

Deininger K et al. (2011) Rising Global Interest in Farmland: Can It Yield Sustainable and Equitable Benefits? (English): Agriculture and Rural Development. Washington, DC: World Bank.

Gathii J and Odumosu-Ayanu I (2016) The turn to contractual responsibility in the global extractive industry. Business and Human Rights Journal 1, 69-94.

Krygier M (2016) The rule of law: pasts, presents and two possible futures. Annual Review of Law and the Social Sciences 12, 199-229. 
Lander J (2020) Transnational Law and State Transformation: The Case of Extractive Development in Mongolia. Abingdon: Routledge.

Muir Watt H (2011) Private international law beyond the schism. Transnational Legal Theory 2, 347-427.

Odumosu-Ayanu I (2014) Governments, investors and local communities: an analysis of a multi-actor investment contract framework. Melbourne Journal of International Law 15, 1-42.

Panesar S (2000) Theories of private property in modern property law. Denning Law Journal 15, 113-138.

Perrone N (2016) The international investment regime and local populations: are the weakest voices unheard? Transnational Legal Theory 7, 383-405.

Rodotà S (1990) Il terribile diritto di proprietà: studi sulla proprietà privata. Bologna: 11 Mulino.

Sassen S (2013) Land grabs today: feeding the disassembling of national territory. Globalizations 10, $25-46$.

Scalisi V (1985) Proprietà e governo democratico dell'economia. Rivista di diritto civile I, 221-239.

Sornarajah M (2010) The International Law on Foreign Investment. Cambridge: Cambridge University Press.

Szoke-Burke S and Cordes K (2017) Mechanisms for Consultation and Free, Prior and Informed Consent in the Negotiation of Investment Contracts, Annual World Bank Conference on Land and Poverty, Washington, DC, 20-24 March 2017.

Violi F (2016) The practice of land grabbing and its compatibility with the exercise of territorial sovereignty. In Seatzu F, Bonfanti A and Romanin Jacur F (eds), Natural Resources Grabbing: An International Law Perspective. Leiden/Boston: Brill/Martinus Nijhoff, pp. 15-37.

Violi F (2017) The regulatory vicious circle of investment operations in agriculture. In Alabrese M (ed.), Current Issues in Agricultural Law in a Global Perspective. Berlin: Springer, pp. 311-340.

Violi F (2020) The function of the triad 'territory', 'jurisdiction', and 'control' in due diligence obligations. In Peters A and Krieger H (eds.), Due Diligence in International Law. Oxford: Oxford University Press, pp. 75-91.

Cite this article: Violi F (2021). Contracting in land and natural resources: a tale of exclusion. International Journal of Law in Context 17, 145-153. https://doi.org/10.1017/S1744552321000094 